Rev. Fac. Ing. - Univ. Tarapacá, vol. 14 Nº 1, 2006, pp. 3-4

EDITORIAL

\title{
NUEVOS CAMINOS EN LA INVESTIGACIÓN CIÉNTÍFICA
}

Las más recientes políticas nacionales en materia de investigación científica tienen como propósito aumentar la capacidad innovadora, esto porque se ha detectado que uno de los factores críticos de nuestro crecimiento como país es la escasa innovación, principalmente tecnológica.

Para aumentar esta capacidad innovadora que el país requiere, es que se están implementando principalmente dos medidas: el aumento de recursos humanos calificados (llámense doctores, investigadores y técnicos); las cifras respecto de este punto hablan claro: Chile cuenta con 3.500 investigadores; en cambio, México cuenta con 25.000, Argentina cuenta con 35.000 y Brasil cuenta con 50.000 (Fuente: Discurso 2.004, Presidente de CONICYT). La fórmula entonces es aumentar especialmente el número de doctores, donde las cifras son porcentualmente iguales a las indicadas anteriormente. La otra medida dice relación con el apoyo decidido a la investigación que conduzca al desarrollo, $\mathrm{I}+\mathrm{D}$, lo que implica vinculación Universidad-Empresa.

El resultado esperado es el aumento de la investigación científica y, por tanto, un impacto en la creación de conocimiento, innovación y finalmente desarrollo sustentable, traducible en calidad de vida y medio ambiente adecuado. Estas políticas nos indican que debemos cambiar.

¿Por qué se debe cambiar?

Indudablemente esta nueva postura implica cambiar la forma tradicional de hacer investigación en las universidades y la fórmula tradicional de captar dinero para investigar.

El hacer investigación, desde la mirada tradicional, se entendía como ganar un concurso, desarrollar la investigación correspondiente e informarla a la Dirección de Investigación y, a veces, no siempre, exponer los resultados en un Congreso, rara vez publicar los resultados. Generalmente el proceso terminaba con la entrega de un informe final y con un certificado que decía que se había concluido satisfactoriamente la investigación. Esta forma de investigar, para muchos, todavía es "la forma". El mayor uso que tenía el "producto" de la investigación era acrecentar el currículo del investigador. Esto se puede ejemplificar diciendo que ha habido académicos que han ganado, durante su trayectoria, proyectos de investigación, con fondos institucionales y que nunca han publicado nada. También quiere decir que el conocimiento logrado quedaba guardado en una oficina y nadie más que los investigadores lo conocían. Constituyen un ejemplo también los proyectos FONDECYT (Fondo Nacional de Desarrollo Científico y Tecnológico), pues esta institución no financia publicaciones y hasta hace unos años tampoco exigía publicaciones en revistas indexadas.

Sin embargo, esta manera de hacer investigación ha ido cambiando, no diría que muy lentamente, pero en un plazo de tres a cuatro años las distintas fuentes que financian investigaciones, en distintos niveles, han ido modificando sus exigencias: FONDECYT (Fondo Nacional de Desarrollo Científico y Tecnológico) solicita como producto publicaciones en revistas indexadas, FONDEF (Fondo de Fomento al Desarrollo Científico y Tecnológico) solicita innovación y desarrollo de nuevos productos, procesos o servicios, o mejoramiento de los existentes, factibles de incorporar al mercado nacional e internacional, las universidades solicitan publicaciones en revistas indexadas (ISI fundamentalmente), etc. 
Estos son cambios que ratifican que hay nuevas políticas para investigación científica en el país y que, por tanto, las universidades debemos, si queremos desarrollarnos como universidad compleja, adecuarnos a ellas, cambiando las que tenemos. Esto también si es que queremos, por esta vía, incrementar el aporte fiscal.

¿Qué y cómo se debe cambiar?

Frente a esta realidad, las universidades tienen la gran tarea. Los estudios y análisis de la realidad de la investigación en las universidades chilenas cada vez son más específicos y detallados, y nos reflejan claramente quiénes somos en materia de investigación; de la misma forma nos señalan cuáles son las tareas más urgentes que cada universidad tiene, de acuerdo a su radiografía. Con esos antecedentes más las políticas nacionales se deben trazar los caminos a seguir, si es que se quiere contribuir al desarrollo de la región y del país.

De acuerdo a lo anterior, las universidades debieran realizar algunos de los siguientes cambios:

1. Convertirse en plataformas de nuevas tecnologías. Hacer quiebres tecnológicos con impacto notorio en la empresa.

2. Incrementar la investigación aplicada y con atención a los problemas de la región en la que está inserta la universidad.

3. Generar innovación para el desarrollo: $\mathrm{I}+\mathrm{D}$ es la fórmula. Es el rasgo distintivo de la investigación actual.

4. Preparar personas con espertizaje técnico en áreas tan específicas como: biohidrometalurgia, automatización y robótica, bioinformática o biología seca, geotécnica, etc. Áreas requeridas en el norte de Chile.

5. Vincular el postgrado con la investigación y la creación de conocimiento.

Estos son algunos ejemplos de cambios y ellos dependen de las características de cada universidad. Además, en todo lo que emprendan, las universidades deben demostrar eficiencia, diferenciación competitiva (tanto por costos como por calidad), adecuación, capacidad de respuesta rápida, flexibilidad, entre otros rasgos.

En todo este escenario, surge otra pregunta: ¿Qué ocurre con las ciencias sociales, con las humanidades? Ellas son vitales para hacer sociedad y dar sentido a los avances del conocimiento; es un cambio que no se ha planificado y que esperamos que se haga como fue prometido también en un discurso público. Por lo tanto, igualmente hay que estar preparados para los cambios que faltan.

Finalmente, la misión de la universidad, su plan estratégico y sus políticas, si queremos entrar en la competencia dura, deben reflejar este nuevo escenario.

Victoria Espinosa Santos

Directora

Dirección Investigación - Universidad de Tarapacá

Arica, Chile 
Rev. Fac. Ing. - Univ. Tarapacá, vol. 14 Nº 1, 2006, pp. 5-6

EDITORIAL

\section{NEW TRENDS IN SCIENTIFIC RESEARCH}

Recent changes in national policies regarding scientific research are geared to increase our capacity for innovation, because a lack of innovation, mainly technological, has been found to slow the country's growth.

In order to increase our capacity for innovation, two initiatives have been undertaken: On the one hand is a plan to increase the number of trained personnel, like doctors, researchers and technicians. The goal of this program is to match the percentage of doctors and researchers of countries with considerably more trained experts such as Brazil (50.000), Argentina (35.000) and Mexico (25.000) The other initiative supports scientific research, so as to strengthen economic development, which implies establishing links between the university and industry.

The desired effect of these measures should produce an increase in scientific research, which should translate into new knowledge, innovation and sustainable development, improving environmental conditions as well quality of life. That is the reason why we must change the present status of scientific research.

Why must we change the way we conduct research?

The rules imposed by the new research policies imply changing the traditional approach to university research, including its funding. Doing research from a traditional perspective was understood as winning a competition for university or public funding, for developing a proposal, reporting the results to the university research committee and sometimes, not always, publishing an article or presenting a paper at a professional conference. The most common goal of the whole process was to expand the researcher's resume. For many people, this is still "the way" to do research at the university, a practice that not uncommonly leads to troublesome situations, in which faculty who have been actively involved in several funded research projects, have never published their results.

This situation has been changing in the last three to four years however. Indeed, research funding agencies have been changing their criteria for allocating funds. FONDECYT (National Fund for Economic, Scientific and Technological Development) and universities are now asking applicants to publish their results in peer reviewed professional journals, mainly those indexed by ISI. In addition, FONDEF (Fund for the Promotion of Scientific and Technological Development) is soliciting research projects designed to develop new products, services and processes, likely to be sold in national and international markets.

What and how to change?

Facing the present reality, it is the role of the University to lead the change. The analysis of research done at institutions of higher education in Chile shows the most urgent needs in scientific research at each university. This change in university policy, combined with new national policies will lead to greater development in the region and in the country.

Considering the above discussion, in order to come to terms with the country's needs, universities should introduce the following changes: 
1. Turning institutions of higher education into centers for new technology that produce significant breakthroughs needed by industry.

2. Increasing applied research on problems of the various regions in which universities are located.

3. Generating innovation to foster development: I+D. This is the trend in today's research.

4. Preparing experts in the following areas: bio hydro metallurgy, artificial intelligence and robotics, bio information or dry biology, geotechnics, etc., which are areas of high demand in northern Chile.

5. Basing graduate programs on scientific research for creating new technological knowledge.

These are examples of possible changes in scientific research policies in our university. Other institutions may have similar or different perspectives on this subject. Still, no matter which changes in policy are undertaken, universities must surely consider efficiency, cost, quality and competitiveness, as well as flexibility to adapt to new environments and quick response when meeting challenges.

Within this context, another question arises: What will happen with the Humanities and the Social Sciences in this new scenario? Both disciplines are crucial in building a new society and in giving direction to the search for knowledge. Despite the fact that these players are not mentioned in the discussion of changes in research policies, we hope they will be included, as promised by public officials.

In closing, if we want to enter this more competitive research arena, the mission, strategic planning and university policies must adjust to this new reality. 